ppi $201502 Z U 4645$

Esta publicación científica en formato digital es continuidad de la revista impresa ISSN-Versión Impresa 0798-1406 / ISSN-Versión on line 2542-3185Depósito legal pp $197402 Z$ U34
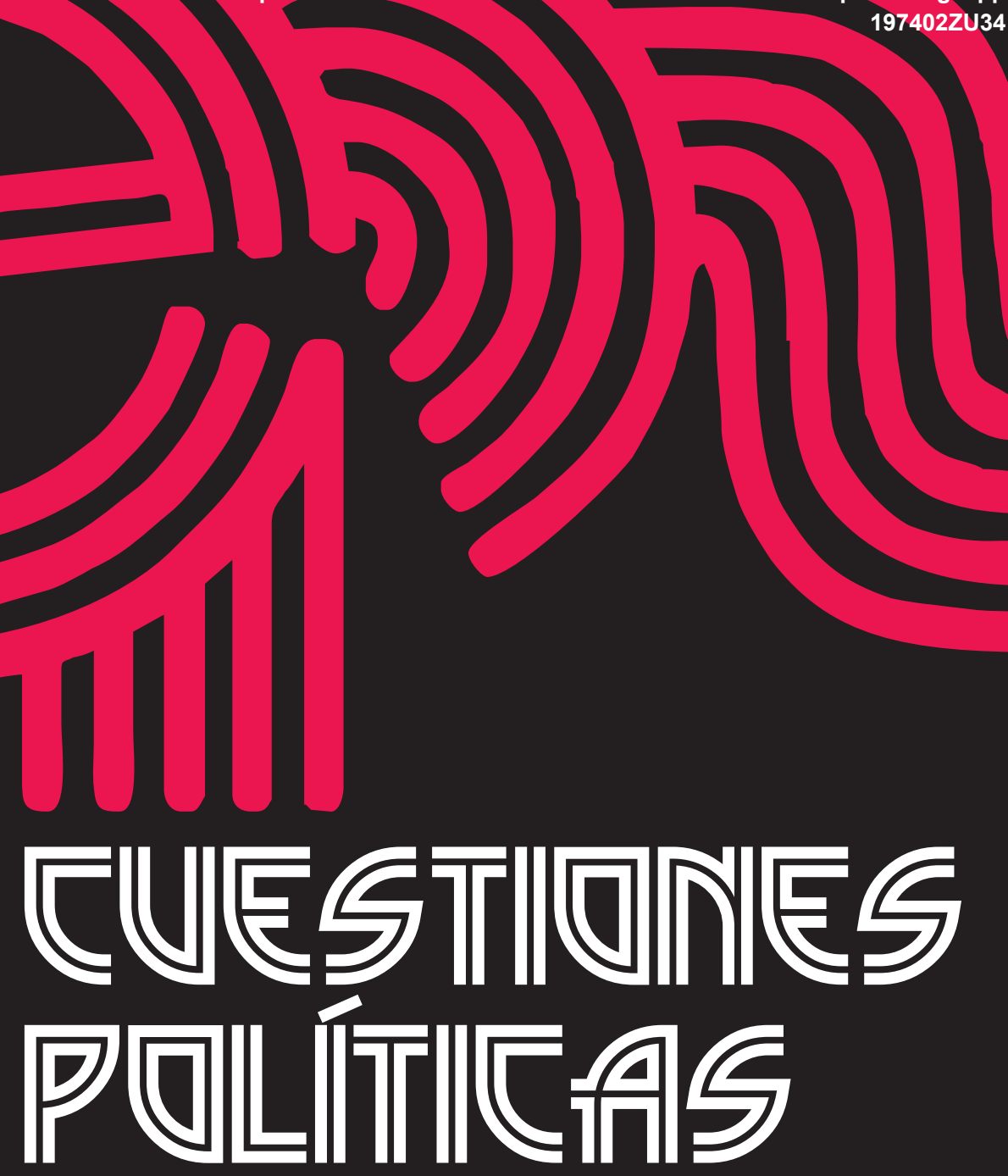

Instituto de Estudios Políticos y Derecho Público "Dr. Humberto J. La Roche" de la Facultad de Ciencias Jurídicas y Políticas de la Universidad del Zulia Maracaibo, Venezuela
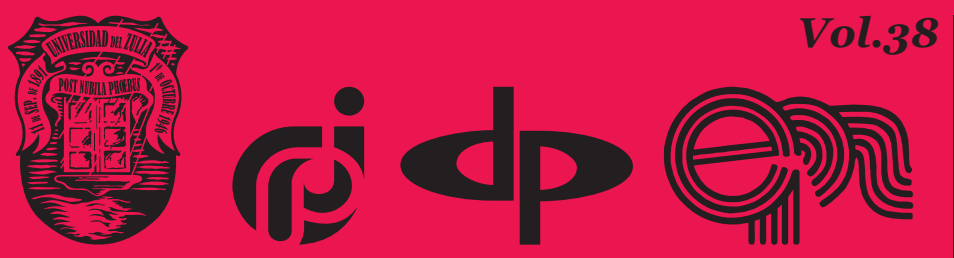

$N^{\circ}$ Especial 2da Parte 2020 


\title{
Socio-Political Tension in the Russian Society: Case Study of Youths of the Republic of Tatarstan
}

\author{
DOI: https://doi.org/10.46398/cuestpol.382e.o5
}

\author{
Sabina Rafailevna Efimova * \\ Evgeniya Valerevna Khramova**
}

\begin{abstract}
This article explores the level of socio-political tension in Tatarstan. The object of the study is the youth social group as a bearer of social activism. The investigation methodology is based on conflict audit technology. Technology involves the use of markers to assess sociopolitical tensions. The main evaluation marker identified a request for social justice. The distinctive characteristics of youth groups are the discretion of group affiliation, the lack of formed ideological attitudes and the latent nature of the formation of the general ideology of various youth communities. The political activism of the Russian youth does not have a pronounced ideological character and is not a decisive factor in the formation of socio-political tensions. It is concluded that the interest in the study of young people who as a group lack common ideological positions is scientifically relevant, even within radicalized communities and with comparative political identities. Consequently, the presence of stable ideological positions will contribute, in principle, to the launching of internal integration processes in these communities and to a stable organization of their discourses and struggles.
\end{abstract}

Keywords: sociopolitical tension; Russian society; social justice; conflict resolution audit; youth in Tatarstan.

Senior Lecturer of Department of Conflict Resolution Studies, Institute of Social and Philosophical Sciences and Mass Communications. ORCID ID: https://orcid.org/oooo-0001-6722-6491. Email: sabimys@gmail.com

** Associate Professor of Department of Conflict Resolution Studies, Institute of Social and Philosophical Sciences and Mass Communications. ORCID ID: https://orcid.org/oooo-0oo1-7281-8731. Email: eugenlic@mail.ru 


\section{Tensión sociopolítica en la sociedad rusa: estudio de caso de jóvenes de la República de Tartaristán}

\section{Resumen}

Este artículo explora el nivel de tensión sociopolítica en Tartaristán. El objeto del estudio es el grupo social juvenil como portador de activismo social. La metodología de investigación se basa en tecnología de auditoría de conflictos. La tecnología implica el uso de marcadores para evaluar las tensiones sociopolíticas. El principal marcador de evaluación identificó una solicitud de justicia social. Las características distintivas de los grupos de jóvenes son: la discreción de la afiliación grupal, la falta de actitudes ideológicas formadas y la naturaleza latente de la formación de la ideología general de varias comunidades juveniles. El activismo político de la juventud rusa no tiene un carácter ideológico pronunciado y no es un factor decisivo en la formación de tensiones sociopolíticas. Se concluye que es relevante científicamente el interés por el estudio de los jóvenes que carecen como grupo de posiciones ideológicas comunes, incluso dentro de comunidades radicalizadas y con identidades políticas comparadas. En consecuencia, la presencia de posiciones ideológicas estables contribuirá, en principio, al lanzamiento de procesos de integración interna en estas comunidades y a una organización estable de sus discursos y luchas.

Palabras clave: tensión sociopolítica; sociedad rusa; justicia social; auditoría de resolución de conflictos; juventud en Tartaristán.

\section{Introduction}

Modern Russian mass media are filled with materials about youth protests in different regions of the country. Youth protest activities are designated as one of the risk-generating zones of Russian politics. In the wake of media interest in this problem, scientific and research interest is growing. The interest is supported by a request for analysis of the quality of the modern Russian youth formation. Attention is drawn to ideological and non-ideological meanings, the bearer of which is the young generation of modern Russia. That is why Russian researchers are increasingly turning to the methodology of generational theory in the study of the youth (Twenge and Generation, 2019; Radaev, 2019; Shamis and Nikonov, 2019).

In addition, there is a search for tools in the study of certain ideological attitudes that can explain the awareness and unconsciousness in the behavior of young people in defending their social and political interests. 
These tools should help in finding out how independent the youths are in determining their political preferences and social activities. They should show how the protest activities of youths affect socio-political tension in society.

The main categories of such an analysis in the presented study are the concepts of "political identity" and "ideological youth extremism". In determining these categories, the authors of the study proceed from the general assumptions of the generative paradigm, which determines the specificity of each new generation of youths. The current generation of 1430 years is defined as "Generation Z". It is non-ideological and has problems with socialization, including politics.

Based on this, modern Russian political scientists define the political identity of the young generation. In particular, G.V. Pushkareva notes the social nature of political identity. She suggests that the political identity of the modern "homo-politicus" is formed as a result of self-determination in the system of political relations (Pushkareva, 2014).

The influence of a group on a person is manifested not only in the additional regulatory regulation of his behavior. Inclusion in a group forms an identity, i.e. a special feeling connecting him with a particular group (Pushkareva, 2014). Based on the group characteristics of political identity, the definition is given to the concept of "ideological extremism". In this context, it is understood as a special kind of conflict (a specific form of negative interaction), characterized by an extreme degree of negation of the opponent.

The study of the processes of inclusion of a young man in political life, political behavior requires methodological tools that take into account the generational characteristics of the identification of subjects and extreme forms of their manifestation. The search for markers of manifestation of the categories "political identity" and "ideological extremism" in the consciousness and behavior of young people is carried out using the method of conflict analysis. This method is a method of qualitative interdisciplinary research (Khramova et al., 2019). It is based on the search for markers in the discourse of socio-political tension. These markers determine the presence or absence of the prerequisites for the growth of tension in the youth environment itself and in society as a whole. Marking is carried out on the basis of the manifestation of youth activity, including political protests.

\section{Methods}

The methodology of the presented analysis is based on the conflictology audit methodology, tested by a group of Kazan (Kazan Federal University) 
and Petersburg (St. Petersburg State University) conflictologists (2019) as part of the Russian grant study. One of the authors of the study presented in this publication is a developer of the indicated methodology and a member of the grant team. Proceeding from this, a conflict resolution audit is considered as a system of technologies used in identifying destructive activities of youths and against them. The conflictology audit methodology is based on the criteria of evaluation, which consists of two components: marker and criteria. The marker component allows you to search for manifestations of activities in the youth discourse of socio-political tension. The criterion component allows you to determine the depth (in numerical equivalent) of the identified activities. The criterion component is based on the tool of the simplest (one-dimensional) scale of the semantic differential.

Markers defined in the study: the de-rationalizing effect of ideological youth extremism on awareness of dissatisfaction with social status; manifestation of requirements; strategies for participating in protest movements; The dominance of the "ideological unconscious" (quasiideologies); The presence of a negative model of identity (for example, excessive identification with the bearers of a particular radical ideology); Lack of formation of political attitudes; Lack of elaborated models of political participation; Lack of experience of political participation using traditional forms; Unrealistic conflict: The dissatisfaction of certain requirements of the participants, the unfair distribution of any advantages between the parties to the conflict, the subjectivity of the assessment (emotionality in the absence of argumentation); "Displaced" and "incorrectly attributed" conflicts (Khramova et al., 2019).

The technology used in conflict auditing is semantic in nature. With its help: the presence / absence of elements of manifestation of ideological youth extremism is determined; a descriptive picture is given of how deeply identified marker is included in the value system of the subject. Objectivization of the subjective nature of qualitative research methods (focus groups and in-depth interviews) is achieved by using the method of semantic differential. Scaling is carried out using detailed rating (point) scales with bipolar labels from o to 10. The studied segments in the structure of youth groups are confessional, gender, opposition and subcultural.

The empirical base of the study presented in the publication comprises of three focus group surveys and fifteen in-depth interviews conducted in Tatarstan, as well as an analytical bank of online materials on youth communities on social networks.

The objectives of the focus group surveys of youths were:

- Analysis of the youth socio-demographic group's rhetoric on communication problems in online and offline communities.

- Analysis of youth affiliation with online and offline radicalized communities. 
Sabina Rafailevna Efimova y Evgeniya Valerevna Khramova
Socio-Political Tension in the Russian Society: Case Study of Youths of the Republic of Tatarstan

- Analysis on the use of "language of aggression" by the young generation in relation to the state and society.

- Determining the position of representatives of the youth formation in cooperation with society and the state.

- Determining the level of understanding of mutual obligations between the youth and these institutions.

\section{Results and Discussion}

According to the results of the study, a number of trends can be identified that affect the formation of the political identity of modern youths and the role of ideological youth extremism in this process. Among the trends: the radicalization of the political mood of the youth group, an increase in the share of ideological youth extremism in the volume of its socio-political activities, the growth of protest activity in the youth environment. The main identified radical youth trends in the Republic of Tatarstan are rightradical (including gender-conflict groups), ultra-liberal, left-radical, streetcriminals, and Islamist (Salafi).

Very often, right-wing youth ideological extremism is repelled by xenophobia and migrantophobia. Two categories are affected by it, students and young specialists. Activization of extremist right-wing radical youth occurs not only during a period of general political instability, but also after individual cases of injustice that affect its values and ideals.

Popular groups among urban youth are gender-masculine groups that see a way out of conflicts with the opposite sex in the creation of a national patriarchy. This is one of the right-wing branches that are gaining popularity among young people.

In fundamentalist communities, a pronounced "extremist text" is not typical. The emphasis is on religious rituals and on a visual bright series. First of all, it is intended for non-Turkic youths of school-student age. Content is popular and animated in nature. There are no voluminous quotes from religious texts and their discussion. The identification of community members follows the principle of differentiation into "We" and "They" similar to other communities.

An analysis of ultra-liberal youth communities revealed the following: The de-rationalizing influence of ideological youth extremism of awareness of dissatisfaction with a social situation; Conflict with the current government for all respondents became an end in itself; Manifestation of the requirements is also in the field of a de-rationalized conflict. Here, the 
fight against corruption is ideologically dominant, without clear ideas about the tools and ways to achieve the demand; the lack of formation of political attitudes is a "red thread" of reasoning in the process of interviewing. Respondents do not declare any political principles, other than the requirement to change the current government.

The most obvious problems for the majority is corruption, polar differentiation between the rich and the poor, and the lack of political freedoms, which is noted both at the regional and national levels. All informants directly or indirectly mention the problem of corruption, believing that due to the presence of corruption in the country, many socioeconomic and political problems are not resolved. No mechanisms other than protest are proposed.

\section{Conclusion}

According to the results of an empirical study, in all youth communities of the examined segments, universal structural signs are found, such as: "Own-Alien (Enemy)" dichotomy; the presence of an ideological leader (only around which a community is viable); a certain set of supporters (according to experts, today it is 20-30 active people in the community); prescribed behaviors of all actors (intolerant of specific Enemies); a nonalternative system of views on reality and a pessimistic vision of the future of society.

The main feature of ideological youth extremism is its reliance on the identity crisis of modern youth, expressed in its negative orientation (denial of similarity with any other age, social, gender or political groups) and fragmentation (a fan of identities is often in a state of existential conflict, because basic identity is not actualized, in the role of which civic identity could play).

This feature of youth identity is actively used by ideologists of extremist movements in their interests, including through manipulative practices. The ideologists positioning the existing government as an Enemy, regardless of the type of extremism, is also an essential feature. It is based on the clearly expressed request of youth (regardless of the type of extremist ideology) for social justice. Proceeding from this, the closer Enemy is opposed by the closer Enemy inner (Ivanov et al., 2019).

The main marker of the formation of the identity of modern Russian youth in the research process is the request for social justice. The distinguishing features of the political identity of youth are discreteness of group affiliation, lack of forming ideological attitudes, and latent nature of the formation of the general ideology of a particular political / politicized youth group. 
Sabina Rafailevna Efimova y Evgeniya Valerevna Khramova
Socio-Political Tension in the Russian Society: Case Study of Youths of the Republic of Tatarstan

The interest for further scientific research, is the problem of young people lacking a demand for common ideological positions even within radicalized and purely political communities. The presence of stable ideological positions will in principle, contribute to the launch of internal integration processes to these communities and a stable recruitment.

In the context of the formation of the political identity of modern Russian youth, we can talk about the signs of the formation in Russia of a kind of "generation of the thirteenth article" (Article 13 of the Constitution of the Russian Federation), which, in denying a single ideology, does not recognize constructive, system-forming, integrating principles of the significance of ideology even within communities, with by which it identifies itself.

According to the results of a regional survey, modern Russian youth is not a significant politically active group for the formation of sociopolitical instability in the country. The thesis imposed by the media that the modern young generation is a generation that goes to protest on ideological convictions is nothing more than a media reason for the formation of discourse. In practice, the lack of formation of the ideological attitudes of young people, the amorphous nature of political identity, and the random (event) nature of its participation in protest actions under the influence of a request for social justice are determined.

\section{Acknowledgements}

The work is performed according to the Russian Government Program of Competitive Growth of Kazan Federal University.

\section{Bibliographic References}

IVANOV, Alexey; KOZLOV, Villiam; BURMISTROVA, Yolliva. 2019. "Followers of the ideology of AUE in the Republic of Tatarstan: factors and actors of negative socialization" In: Kazan Pedagogical Journal. Vol. 6, pp. 211214.

KHRAMOVA, Edward; BOLSHAKOV, Andrey; IVANOV, Alexey; SHIBANOVA, Natalia. 2019. "Conflictology audit methodology: application practices in the study of aggression in the educational environment and youth ideological extremism" In: Kazan Pedagogical Journal. Vol. 6, pp. 205210. 


\section{CUESTIONES POLÍTICAS}

Vol. $38 \mathrm{~N}^{\circ}$ Especial (2da parte 2020): 68-75

PUSHKAREVA, Galina V. 2014. Homo politicus: a political man. ArgamakMedia, 336. Russia.

RADAEV, Villiam. 2019. Millennials: How Russian society is changing. Nat researched University "Higher School of Economics". Publishing. House of the Higher School of Economics. Moscow, Russia.

SHAMIS, Evgeniya; NIKONOV, Edward. 2019. The family is not without Millennium. What to do to the generation (b. 1985-2002) that changes the world. M.: Synergy book. Moscow, Russia

TWENGE, David; GENERATION, Iidema. 2019. Why did the Internet generation lose its rebellious spirit, became more tolerant, less happy and absolutely unprepared for adulthood (trans. from English A. Tolmacheva). RIPOL Classic Group of Companies. Moscow, Russia. 
Vol.38 NEspecial

Esta revista fue editada en formato digital y publicada en diciembre de 2020, por el Fondo Editorial Serbiluz, Universidad del Zulia. Maracaibo-Venezuela 